\title{
Analisis Pengaruh Direktur dan Komisaris Wanita terhadap Performa Perusahaan Asuransi Jiwa di Indonesia
}

\author{
Arya Kandrasyah ${ }^{1}$ \\ Fakultas Ekonomi dan Bisnis \\ Universitas Indonesia, Indonesia. \\ Email: arya.kandrasyah@gmail.com \\ Graciala Denita ${ }^{3}$ \\ Fakultas Ekonomi dan Bisnis \\ Universitas Indonesia, Indonesia.
}

\author{
Dyah Ambar \\ Fakultas Ekonomi dan Bisnis \\ Universitas Indonesia, Indonesia.
}

\author{
Musa Fresno ${ }^{4}$ \\ Fakultas Ekonomi dan Bisnis \\ Universitas Indonesia, Indonesia.
}

\author{
Dewi Hanggraeni ${ }^{5}$ \\ Fakultas Ekonomi dan Bisnis \\ Universitas Indonesia, Indonesia.
}

\begin{abstract}
ABSTRAK
Penelitian ini memiliki tujuan untuk mengetahui apakah komposisi dan atribut wanita pada jajaran dewan berpengaruh terhadap performa perusahaan asuransi jiwa di Indonesia. Metode yang digunakan dalam penelitian ini adalah metode kuantitatif, dengan teknik pengolahan data pooled least square multiple regression. Sampel yang digunakan adalah 22 perusahaan asuransi jiwa di Indonesia pada periode 2014-2018. Penelitian memiliki hasil bahwa komposisi wanita dalam jajaran dewan berpengaruh terhadap performa perusahaan asuransi jiwa di Indonesia. Sedangkan atribut edukasi dan rangkap jabatan (multidirectorship), serta tata kelola perusahaan berpengaruh terhadap performa perusahaan asuransi jiwa di Indonesia.

Kata Kunci : $\quad$ Performa; Direktur Wanita; Komisaris Wanita; Tata Kelola; Asuransi Jiwa.

\section{The Effect Analysis of Female Director and Commissioner on Life Insurance Company Performance in Indonesia}

\footnotetext{
ABSTRACT

This research aims to determine whether the composition and attributes of female in the company's board influence the performance of life insurance companies in Indonesia. The method used in this research is quantitative method, with pooled least square multiple regression technique. This research sample consist of 22 life insurance company in Indonesia on the 2014-2018 period. This research result shows that the female composition on the company's board influences the performance of life insurance companies in Indonesia. While the educational and multi-directorship attributes, as well as corporate governance affect the performance of life insurance companies in Indonesia.

$\begin{array}{ll}\text { Keywords: } & \text { Performance; Female director; Female } \\ & \text { commissioner; Corporate Governance; Life } \\ & \text { Insurance. }\end{array}$
}

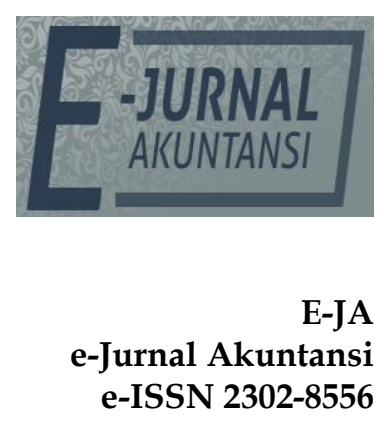

Vol. 29 No. 3

Denpasar, Desember

Hal. 1132-1151

Artikel masuk: 25 Oktober 2019

Tanggal diterima: 23 Desember 2019 


\section{PENDAHULUAN}

Performa perusahaan merupakan hal yang penting dan menjadi indikator kelayakan bagi investor untuk berinvestasi di perusahaan. Penyebab naik atau turunnya performa perusahaan dapat disebabkan karena faktor internal dan eksternal. Salah satu faktor internal yang menjadi penyebab turunnya performa perusahaan adalah kemampuan organisasi dalam melakukan tata kelola perusahaan. Menurut Pedoman Umum Good Corporate Governance Indonesia, organ perusahaan terdiri dari Rapat Umum Pemegang Saham, direksi, dan dewan komisaris. Ketiga organ ini memiliki peran penting dalam pelaksanaan tata kelola perusahaan (good corporate governance). Salah satu hal yang diatur dalam tata kelola perusahaan adalah terkait dengan risiko kepengurusan.

Risiko kepengurusan adalah risiko kegagalan perusahaan dalam mencapai tujuan perusahaan akibat kegagalan perusahaan dalam memelihara komposisi terbaik pengurus yang memiliki kompetensi dan integritas yang tinggi. Pengurus yang dimaksud dalam risiko kepengurusan adalah direksi dan dewan komisaris. Tujuan utama manajemen risiko kepengurusan adalah memastikan perusahaan dapat menjaga komposisi direksi dan dewan komisaris terbaik yang memiliki kompetensi dan integritas yang tinggi, sehingga perusahaan dapat mencapai tujuan (OJK, n.d.)

Risiko kepengurusan erat kaitannya dengan komposisi direksi dan dewan komisaris pada suatu perusahaan. Terdapat hubungan positif antara gender diversity dalam komposisi direksi dan dewan komisaris terhadap performa perusahaan (Campbell \& Mínguez-Vera, 2008). Selain itu, atribut dari direktur wanita seperti pengalaman, keahlian, karakteristik demografis berkontribusi terhadap efektivitas dari kegiatan monitor dan pengambilan keputusan dari suatu perusahaan (Johnson, Schnatterly, \& Hill, 2013). Struktur dewan yang terdiri dari direksi dan dewan komisaris memiliki pengaruh terhadap performa perusahaan, khususnya untuk perusahaan publik dengan potensi masalah keagenan karena terpisahnya antara kepemilikan dan kontrol perusahaan (Fauzi \& Locke, 2012). Berdasarkan hal tersebut, pengaruh komposisi direktur dan komisaris wanita terhadap performa perusahaan menarik untuk diteliti.

Berdasarkan Global Board Diversity Tracker Report 2018, terdapat 84,9 persen perusahaan besar di 44 negara yang memasukkan paling tidak satu anggota wanita ke dalam jajaran direksi dan dewan komisaris (IFC, 2018). Secara keseluruhan, 20,4 persen direktur dan komisaris dari seluruh negara yang diteliti dalam Global Board Diversity Tracker adalah wanita. Persentase ini naik dari angka 13,6 persen pada tahun 2012. Berdasarkan Board Gender Diversity Report 2017, persentase wanita yang menjabat sebagai direktur dan komisaris di Indonesia adalah 14,9 persen. Persentase ini lebih tinggi dari Malaysia (13,5 persen), Filipina (13,2 persen), Singapura (11,9 persen), dan China (12,7 persen).

Meski persentase wanita yang menjabat sebagai direktur dan komisaris di Indonesia tinggi, persentase direktur dan komisaris pada asuransi jiwa di Indonesia terbilang rendah. Dalam lima tahun terakhir, lebih dari 50 persen sampel perusahaan asuransi jiwa di Indonesia tidak memiliki anggota wanita dalam jajaran direksi dan dewan komisaris setidaknya untuk satu periode.

Artikel ini membahas pengaruh keberagaman gender direktur dan komisaris terhadap performa perusahaan asuransi jiwa di Indonesia. 
Penggunaan sampel perusahaan asuransi jiwa di Indonesia merupakan kebaruan yang ditawarkan oleh penelitian kami, dikarenakan penelitian serupa yang dilakukan oleh (Bennouri, Chtioui, Nagati, \& Nekhili, 2018) menggunakan jenis perusahaan umum di Perancis. Dalam menguji pengaruh keberagaman gender direktur dan komisaris terhadap performa perusahaan asuransi jiwa di Indonesia, kami juga menggunakan atribut dari direktur dan komisaris berjenis kelamin wanita lainnya, yaitu: latar belakang pendidikan, keahlian bisnis, rangkap jabatan (multi-directorship), dan masa jabatan (tenure). Selain itu, kami juga menggunakan dua atribut yang mengukur pengaruh tata kelola perusahaan terhadap performa perusahaan asuransi jiwa di Indonesia: ukuran jajaran dewan dan independensi dewan.

Berdasarkan uraian di atas, maka rumusan masalah adalah, 1. Apakah komposisi direktur dan komisaris wanita berpengaruh terhadap performa perusahaan asuransi jiwa di Indonesia? 2. Apakah latar belakang pendidikan direktur dan komisaris wanita berpengaruh terhadap performa perusahaan asuransi jiwa di Indonesia? 3. Apakah keahlian bisnis direktur dan komisaris wanita berpengaruh terhadap performa perusahaan asuransi jiwa di Indonesia? 4. Apakah rangkap jabatan (multi-directorship) direktur dan komisaris wanita berpengaruh terhadap performa perusahaan asuransi jiwa di Indonesia? 5. Apakah lama jabatan (tenure) direktur dan komisaris wanita berpengaruh terhadap performa perusahaan asuransi jiwa di Indonesia? 6. Apakah ukuran dewan komisaris dan direksi berpengaruh terhadap performa perusahaan asuransi jiwa di Indonesia? 7. Apakah independensi dewan komisaris berpengaruh terhadap performa perusahaan asuransi jiwa di Indonesia?

Penelitian ini memberikan manfaat bagi penelitian selanjutnya, akademisi, dan praktisi perusahaan asuransi jiwa. Untuk penelitian selanjutnya, diharapkan penelitian kami memberikan peluang untuk penelitian selanjutnya dan memberikan gambaran research gap yang belum diteliti pada penelitian ini. Untuk akademisi, diharapkan penelitian kami dapat memberikan wawasan terkait pengaruh direksi dan komisaris wanita terhadap performa perusahaan asuransi jiwa di Indonesia. Untuk praktisi perusahaan asuransi jiwa, diharapkan penelitian ini juga dapat dijadikan referensi dalam pengaturan komposisi direksi dan komisaris wanita pada perusahaan asuransi jiwa di Indonesia.

Beberapa penelitian dan literatur sebelumnya menunjukkan pengaruh dari adanya keberagaman gender pada dewan komisaris dan direksi terhadap performa perusahaan. Gender diversity memiliki berpengaruh secara positif terhadap performa perusahaan (Campbell \& Mínguez-Vera, 2008). Temuan ini mendukung hipotesis yang mengatakan bahwa terdapat pengaruh positif antara keberadaan wanita dalam susunan board (direksi dan dewan komisaris) terhadap performa perusahaan (Bennouri et al., 2018). Berdasarkan hal ini, rumusan masalah dalam penelitian ini adalah sebagai berikut:

$\mathrm{H}_{1}$ : Komposisi direktur wanita berpengaruh secara positif terhadap performa perusahaan asuransi jiwa di Indonesia.

$\mathrm{H}_{2}$ : Komposisi komisaris wanita berpengaruh secara positif terhadap performa perusahaan asuransi jiwa di Indonesia.

Karakteristik direktur dan komisaris seperti kemampuan teknikal, kemampuan direksi, dan latar belakang sosial dapat meningkatkan kemampuan 
dalam menjalankan fungsi sehingga dapat berpengaruh kepada performa perusahaan (Johnson et al., 2013). Atribut demografis dari direksi dan komisaris berpengaruh pada efektivitas dari direksi walaupun dapat memperlambat proses pengambilan keputusan (Milliken \& Martins, 1996). Terdapat beberapa hal yang dapat diukur dari karakteristik demografis direksi dan komisaris. Karakteristik pertama adalah edukasi. Semakin tinggi tingkat edukasi direktur dan komisaris, semakin direktur dan komisaris tersebut dapat memahami, menganalisis, dan menawarkan solusi terhadap masalah yang kompleks (Johnson et al., 2013). Selain itu, komisaris wanita dengan tingkat pendidikan lebih tinggi memiliki dampak terhadap diskusi dan terdapat hubungan positif antara performa perusahaan dan tingkat edukasi direksi dan komisaris (Singh, Point, Moulin, \& Davila, 2015). Selain edukasi, pengetahuan tentang bisnis juga memengaruhi performa perusahaan (Ruigrok, Peck, \& Tacheva, 2007). Selanjutnya, dirumuskan hipotesis sebagai berikut:

$\mathrm{H}_{3}$ : Latar belakang pendidikan direktur dan komisaris wanita berpengaruh secara positif terhadap performa perusahaan asuransi jiwa di Indonesia.

$\mathrm{H}_{4}$ : Keahlian bisnis direktur dan komisaris wanita berpengaruh secara positif terhadap performa perusahaan asuransi jiwa di Indonesia.

Beberapa penelitian melaporkan bahwa direktur wanita lebih banyak merangkap jabatan (multi-directorship) dibandingkan direktur laki-laki. Direksi yang lebih banyak rangkap jabatan (multi-directorship) memiliki kecenderungan untuk memiliki pengetahuan lingkungan bisnis yang lebih baik, ditambah lagi IPO dari suatu perusahaan memiliki value yang lebih baik ketika memiliki direktur yang sibuk (Hillman, Harris, \& Cannella, 2012). Oleh sebab itu, hipotesis dirumuskan sebagai berikut.

$\mathrm{H}_{5}$ : Rangkap jabatan (multi-directorship) direktur dan komisaris wanita memiliki pengaruh positif terhadap performa perusahaan asuransi jiwa di Indonesia.

Tenure dari direksi menunjukkan tingkat pengetahuan dan juga pengalaman di perusahaan tersebut (Harris \& Shimizu, 2004). Selain itu, perusahaan memiliki insentif untuk mempertahankan direktur dan pada akhirnya menambah pengetahuan terhadap direksi tersebut (McDonald, Westphal, \& Graebner, 2008). Waktu tenure yang lebih lama berpengaruh positif terhadap performa perusahaan melalui tingkat efikasi dari direksi. Oleh sebab itu, peneliti memiliki hipotesis sebagai berikut.

$\mathrm{H}_{6}$ : Tenure direktur dan komisaris wanita memiliki pengaruh positif terhadap performa perusahaan asuransi jiwa di Indonesia.

Perusahaan yang menerapkan prinsip good corporate governance akan memiliki performa yang lebih baik (Bhagat \& Bolton, 2019). Tata kelola perusahaan dapat dinilai melalui komposisi dan kepatuhan dari jajaran, yaitu ukuran jajaran dewan, persentase komisaris independen, serta lama presiden direktur bekerja di perusahaan (Adams \& Ferreira, 2009; Terjesen, Couto, \& Francisco, 2016). Komisaris independen akan memiliki potensi lebih rendah terjadinya konflik kepentingan sehingga memiliki integritas yang lebih tinggi dan dapat memberikan penilaian yang tidak memihak (Fama, 1980; Rosenstein \& Wyatt, 1997). Selain itu, ukuran jajaran berpengaruh secara negatif terhadap performa perusahaan (Guest, 2009). Masa jabatan dari presiden direktur memiliki pengaruh yang positif terhadap performa perusahaan (Junyon \& Xian, 
2015). Dengan tiga atribut tata kelola diatas, peneliti memiliki hipotesis sebagai berikut

$\mathrm{H}_{7}$ : Ukuran jajaran dewan komisaris dan direksi memiliki pengaruh negatif terhadap performa perusahaan asuransi jiwa di Indonesia.

$\mathrm{H}_{8}$ : Independensi dewan komisaris memiliki pengaruh positif terhadap performa perusahaan asuransi jiwa di Indonesia.

Terdapat dua variabel kontrol dalam penelitian ini: leverage dan firm size. Leverage memiliki efek negatif terhadap performa rata-rata perusahaan (Maina, Olweny, \& Wanjau, 2018; Tsuruta, 2017). Sementara itu, firm size merupakan indikator aset total memiliki hubungan positif terhadap performa perusahaan yang diukur dengan profitabilitas (Alex \& Ngaba, 2018; Doğan, 2013).

\section{METODE PENELITIAN}

Penelitian ini bersifat kuantitatif dan merupakan studi kausal. Studi kausal menguji apakah satu variabel memengaruhi perubahan variabel lain atau tidak (Sekaran, 2011). Metode kuantitatif adalah metode yang digunakan dalam penelitian ini. Berikut adalah model konseptual yang digunakan dalam penelitian ini:

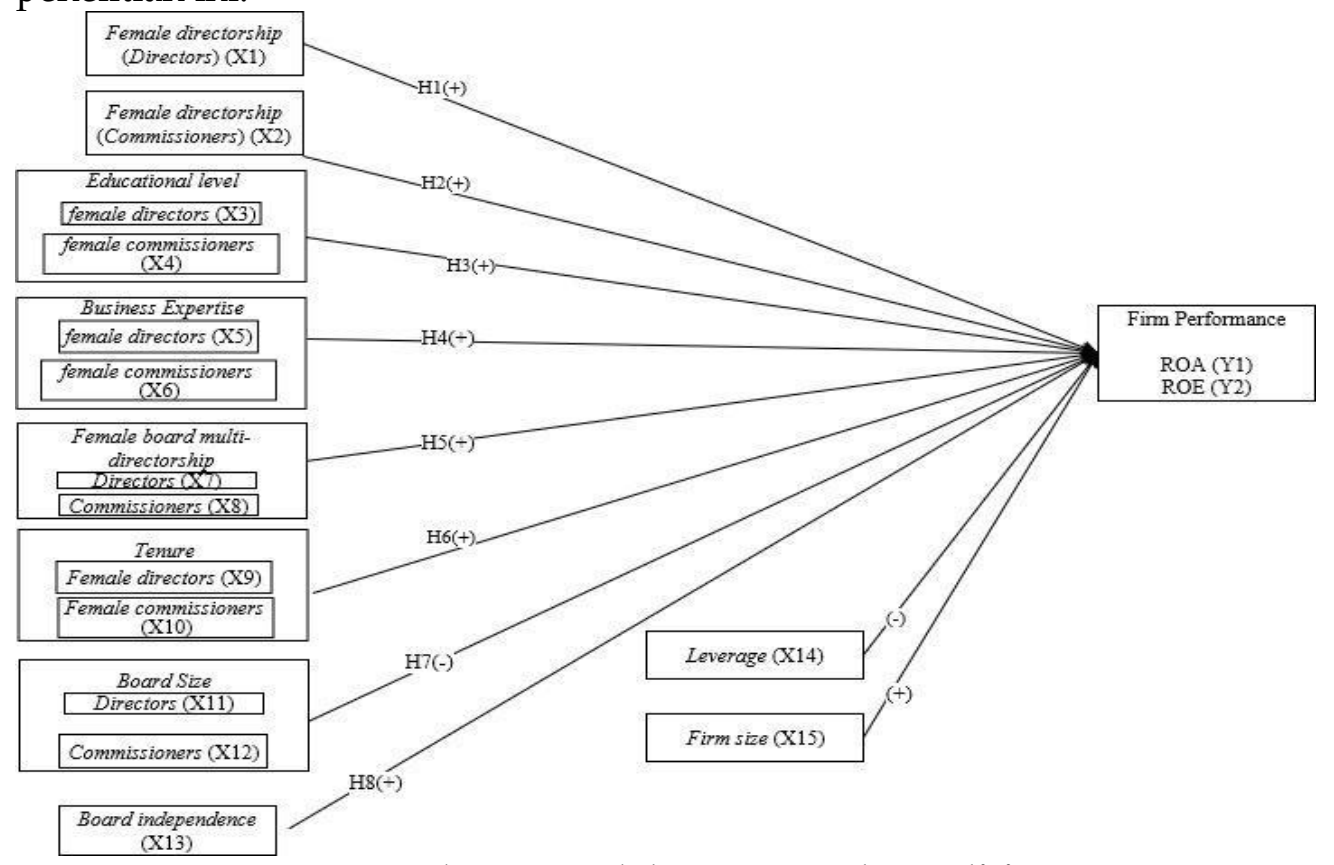

\section{Gambar 1. Model Konseptual Penelitian}

Sumber: Bennouri et al. (2018)

Objek penelitian adalah perusahaan asuransi jiwa di Indonesia. Kriteria pemilihan sampel adalah (1) perusahaan asuransi jiwa yang mempublikasikan laporan keuangan ataupun laporan tahunan dari tahun 2014 hingga 2018, (2) perusahaan asuransi jiwa yang memiliki informasi mengenai data-data yang dibutuhkan dalam penelitian ( $R O A, R O E$, komposisi direktur wanita, komposisi komisaris wanita, tingkat pendidikan direktur wanita, tingkat pendidikan komisaris wanita, keahlian bisnis direktur wanita, keahlian bisnis komisaris wanita, rangkap jabatan (multi-directorship) direktur wanita, rangkap jabatan (multi-directorship) komisaris wanita, tenure direksi wanita, tenure komisaris 
wanita, ukuran jajaran dewan, independensi dewan, tenure presiden direktur, leverage, dan firm size. Berdasarkan kriteria sampel, diperoleh 22 perusahaan asuransi jiwa di Indonesia dengan data lima tahun (2014-2018). Berikut adalah perusahaan yang menjadi sampel dalam penelitian:

\section{Tabel 1. Sampel Perusahaan Asuransi Jiwa di Indonesia}

\begin{tabular}{lllll}
\hline Nomor & $\begin{array}{l}\text { Nama Perusahaan } \\
\text { Asuransi Jiwa }\end{array}$ & $\begin{array}{l}\text { Total Aset } \\
\text { (Rp miliar) }\end{array}$ & $\begin{array}{l}\text { ROA } \\
\text { ( persen) }\end{array}$ & $\begin{array}{l}\text { ROE } \\
\text { (persen) }\end{array}$ \\
\hline 1. & Manulife Indonesia & 47,36 & 5,51 & 22,65 \\
2. & AXA Mandiri & $29.576,15$ & 3,34 & 47,52 \\
3. & BNILIFE & $17.287,80$ & 1,07 & 3,55 \\
4. & BRILIFE & $9.356,50$ & 6,42 & 26,90 \\
5. & Paninvest & $30.209,05$ & 7,09 & 8,32 \\
6. & Astra Life & $4.812,77$ & $-2,25$ & $-21,48$ \\
7. & Sinarmas MSIG & $15.551,81$ & 2,40 & 5,20 \\
8. & FWD & $1.484,21$ & $-32,85$ & $-162,62$ \\
9. & AIA Financial & 229,81 & 1,40 & 8,27 \\
10. & Allianz Life & 897,57 & 0,86 & 12,10 \\
11. & Commonwealth Life & $7.536,19$ & 4,17 & 15,37 \\
12. & Indosurya Life & $1.290,41$ & $-6,61$ & $-76,25$ \\
13. & Cigna & $1.671,16$ & $-2,24$ & $-6,38$ \\
14. & Taspen Life & $3.459,84$ & 2,19 & 18,65 \\
15. & PFI Mega Life & $1.011,94$ & 5,93 & 21,82 \\
16. & Chubb Life & $2.735,67$ & 4,46 & 20,35 \\
17. & Avrist & $10.229,51$ & 2,43 & 13,90 \\
18. & Sequis Life & $18.420,33$ & 3,33 & 9,63 \\
19. & Great Eastern Life & $4.552,77$ & 0,20 & 1,58 \\
20. & Generali & $6.994,87$ & 2,57 & 17,56 \\
21. & Zurich Topas Life & $1.192,30$ & $-54,69$ & $-150,27$ \\
22. & Indolife & $28.475,77$ & 0,51 & 2,40 \\
\hline
\end{tabular}

Sumber: Data Penelitian, 2019

Terdapat tiga jenis variabel yang digunakan dalam penelitian: variabel dependen, independen, dan kontrol. Variabel dependen yang digunakan adalah ROA (Y1) dan ROE (Y2). Variabel independen meliputi: female directorship (direktur) (X1), female directorship (komisaris) (X2), educational level of female directors (X3), educational level of commissioners (X4), business expertise of female directors (X5), business expertise of female commissioners (X6), female board multidirectorship (direktur) (X7), female board multi-directorship (komisaris) (X8), tenure of female directors (X9), tenure of female commissioner (X10), board size (direksi) (X11), board size (komisaris) (X12), board independence (X13), leverage (X14), dan firm size (X15).

Dua variabel dependen yang digunakan adalah ROE (return on equity) dan ROA (return on asset). Ukuran performa perusahaan yang berhubungan dengan performa akuntansi pemegang saham. Pengukuran dengan membagi laba bersih dengan ekuitas pemegang saham setiap perusahaan asuransi jiwa di Indonesia yang menjadi sampel. Informasi mengenai performa keuangan tersebut didapatkan pada laporan keuangan selama lima tahun. Menurut Ross, Westerfield, \& Bradford D. Jordan (2012), ROA (Y1) dirumuskan sebagai berikut: 


$$
R O A=\frac{\text { Net income }}{\text { Total Assets }}
$$

Performa yang menghitung rasio laba bersih terhadap total aset. Merupakan indikator profitabilitas yang dapat mengukur performa manajemen dalam mengelola kekayaan perusahaan. Semua data yang dibutuhkan disajikan dalam laporan keuangan berisikan perhitungan performa sebagai tanggung jawab perusahaan kepada pemegang saham. Menurut Ross et al. (2012), ROE (Y2) dirumuskan sebagai berikut:

$$
R O E=\frac{\text { Net Income }}{\text { Stockholders' Equity. }}
$$

Variabel independen adalah Female directorship direktur (X1) diukur dari rasio perbandingan antara jumlah direktur wanita dengan seluruh jajaran direksi yang menjabat pada tahun yang bersangkutan. Female directorship komisaris (X2) diukur dari rasio perbandingan antara jumlah direktur wanita dengan seluruh jajaran dewan komisioner yang menjabat pada tahun yang bersangkutan. Educational level of female directors (X3) adalah jumlah direksi wanita yang menempuh pendidikan minimal hingga strata-2 ke atas dibagi dengan jumlah direktur wanita di perusahaan. Educational level of female commissioners (X4) adalah jumlah dewan komisioner wanita yang menempuh pendidikan minimal menyelesaikan studi strata-2 lalu dibagi dengan jumlah komisioner wanita di perusahaan.

Variabel Business expertise of female directors (X5) adalah jumlah direktur wanita yang menempuh pendidikan minimal strata-1 pada program studi yang berkaitan dengan bisnis atau ekonomi dibagi dengan jumlah direktur di perusahaan. Variabel Business expertise of female commissioners (X6) adalah jumlah dewan komisioner wanita yang menempuh pendidikan minimal strata-1 pada program studi yang berkaitan dengan bisnis atau ekonomi dibagi dengan jumlah direktur di perusahaan. Kedua variabel mengenai Business expertise merupakan bentuk dari keahlian wanita pada jajaran manajemen puncak pada performa keuangan perusahaan.

Female board multi-directorship direktur (X7) adalah variabel yang membahas apakah direktur wanita merangkap jabatan di perusahaan yang berbeda terhadap total direktur wanita. Female board multi-directorship komisaris (X8) adalah variabel yang membahas apakah komisaris wanita merangkap jabatan di perusahaan yang berbeda terhadap total direktur wanita. Tenure of female directors (X9) yang membagi rata durasi direktur wanita di perusahaan tersebut untuk mendapatkan posisi direktur sebut. Tenure of female commissioner (X10) yang membagi rata durasi komisioner wanita di perusahaan tersebut untuk mendapatkan posisi direktur sebut.

Variabel independen lainnya adalah Board size direktur (X11) yaitu besarnya merupakan jumlah board of director, sementara Board size komisaris (X12) yang merupakan besaran jumlah dari dewan komisaris di perusahaan yang bersangkutan.

Variabel terakhir adalah Board independence yaitu jumlah dewan komisaris independen yang lalu dibagi dengan total dewan komisaris mengikuti kebijakan di indonesia. 
Variabel kontrol adalah leverage dan firm size. Leverage adalah rasio total kewajiban terhadap total aset. Leverage terkait dengan struktur modal perusahaan. Apakah pembiayaan modal perusahaan menunjukkan ada risiko utang atau kewajiban yang tidak mampu terbayar? Bagaimana komposisi pembiayaan utang dan pemegang ekuitas saham? Menurut Bennouri et al. (2018); Miller \& Del Carmen Triana, (2009); Terjesen, Sealy, \& Singh, (2009), Leverage dirumuskan sebagai berikut:

$$
\text { Leverage }=\frac{\text { Total Liabilities }}{\text { Total Assets }}
$$

Variabel kontrol lainnya adalah firm size. Variabel ini didapat dari logaritma natural dari total aktiva sebagai cerminan besar kecilnya perusahaan. Log natural merupakan cara untuk mentransformasi data total aset perusahaan yang beragam. Menurut Bennouri et al. (2018); Terjesen et al. (2009), Size perusahaan dirumuskan sebagai berikut:

\section{Firm Size $=\ln ($ total assets $)$}

Pada penelitian ini, terdapat beberapa teknik analisis dan pengujian data yang digunakan: analisis statistik deskriptif, uji asumsi klasik (uji normalitas residual, uji multikolinearitas, uji heteroskedastisitas, dan uji autokorelasi), dan pooled least square multiple regression. Persamaan yang digunakan dalam pengolahan pooled least square multiple regression adalah sebagai berikut:

\section{Persamaan 1:}

$$
\begin{aligned}
& \mathrm{Y}_{1 i t}=\boldsymbol{\alpha}+\boldsymbol{\beta}_{1} \mathrm{X}_{1 i t}+\boldsymbol{\beta}_{2} \mathrm{X}_{2 i t}+\boldsymbol{\beta}_{3} \mathrm{X}_{3 i t}+\boldsymbol{\beta}_{4} \mathrm{X}_{4 i t}+\boldsymbol{\beta}_{5} \mathrm{X}_{5 i t}+\boldsymbol{\beta}_{6} \mathrm{X}_{6 i t}+\boldsymbol{\beta}_{7} \mathrm{X}_{7 i t}+\boldsymbol{\beta}_{8} \mathrm{X}_{8 i t}+ \\
& \boldsymbol{\beta}_{9} \mathrm{X}_{9 i t}+\boldsymbol{\beta}_{10} \mathrm{X}_{10 i t}+\boldsymbol{\beta}_{11} \mathrm{X}_{11 i t}+\boldsymbol{\beta}_{12} \mathrm{X}_{12 i t}+\boldsymbol{\beta}_{13} \mathrm{X}_{13 i t}+\boldsymbol{\beta}_{14} \mathrm{X}_{14 i t}+\boldsymbol{\beta}_{15} \mathrm{X}_{15 i t}+\boldsymbol{\beta}_{16} \mathrm{X}_{16 i t}+\mathrm{e}
\end{aligned}
$$

Sumber: Bennouri et al. (2018),

Keterangan:

$\mathrm{Y}_{1 i t}=$ ROA perusahaan asuransi jiwa ke-i pada periode $\mathrm{t}$

$\boldsymbol{\alpha}=$ Konstanta

$\mathrm{X}_{1 i t}=$ Female directorship (direktur) perusahaan asuransi jiwa ke-i pada periode $\mathrm{t}$

$\mathrm{X}_{2 i t}=$ Female directorship (komisaris) perusahaan asuransi jiwa ke-i pada periode $\mathrm{t}$

$\mathrm{X}_{3 i t}=$ Educational level of female directors perusahaan asuransi jiwa ke-i pada periode $\mathbf{t}$

$\mathrm{X}_{4 i t}=$ Educational level of commissioners perusahaan asuransi jiwa ke-i pada periode $\mathrm{t}$

$\mathrm{X}_{5 i t}=$ Business expertise of female directors perusahaan asuransi jiwa ke-i pada periode $\mathrm{t}$

$\mathrm{X}_{6 i t}=$ Business expertise of female commissioners perusahaan asuransi jiwa ke-i pada periode $\mathrm{t}$

$\mathrm{X}_{7 i t}=$ Female board multi-directorship (direktur) perusahaan asuransi jiwa ke-i pada periode $\mathrm{t}$

$\mathrm{X}_{8 i t}=$ Female board multi-directorship (komisaris) perusahaan asuransi jiwa ke-i pada periode $\mathrm{t}$

$\mathrm{X}_{\text {iit }}=$ Tenure of female directors perusahaan asuransi jiwa ke-i pada periode $\mathrm{t}$

$\mathrm{X}_{10 i t}=$ Tenure of female commissioner perusahaan asuransi jiwa ke-i pada periode $\mathrm{t}$

$\mathrm{X}_{11 i t}=$ Board size (direksi) perusahaan asuransi jiwa ke-i pada periode $\mathrm{t}$

$\mathrm{X}_{12 i t}=$ Board size (komisaris) perusahaan asuransi jiwa ke-i pada periode $\mathrm{t}$

$\mathrm{X}_{13 i t}=$ Board independence perusahaan asuransi jiwa ke-i pada periode $\mathrm{t}$

$\mathrm{X}_{14 i t}=$ leverage perusahaan asuransi jiwa ke-i pada periode $\mathrm{t}$

$\mathrm{X}_{15 i t}=$ firm size perusahaan asuransi jiwa ke-i pada periode $\mathrm{t}$

$\boldsymbol{\beta}_{1-15}=$ Koefisien parameter $\mathrm{X}_{1-15}$ 
$\mathrm{e}=$ error

Persamaan 2:

$\mathrm{Y}_{2 i t}=\boldsymbol{\gamma}+\boldsymbol{\theta}_{1} \mathrm{X}_{1 i t}+\boldsymbol{\theta}_{2} \mathrm{X}_{2 i t}+\boldsymbol{\theta}_{3} \mathrm{X}_{3 i t}+\boldsymbol{\theta}_{4} \mathrm{X}_{4 i t}+\boldsymbol{\theta}_{5} \mathrm{X}_{5 i t}+\boldsymbol{\theta}_{6} \mathrm{X}_{6 i t}+\boldsymbol{\theta}_{7} \mathrm{X}_{7 i t}+\boldsymbol{\theta}_{8} \mathrm{X}_{8 i t}+$

$\boldsymbol{\theta}_{9} \mathrm{X}_{9 i t}+\boldsymbol{\theta}_{10} \mathrm{X}_{10 i t}+\boldsymbol{\theta}_{11} \mathrm{X}_{11 i t}+\boldsymbol{\theta}_{12} \mathrm{X}_{12 i t}+\boldsymbol{\theta}_{13} \mathrm{X}_{13 i t}+\boldsymbol{\theta}_{14} \mathrm{X}_{14 i t}+\boldsymbol{\theta}_{15} \mathrm{X}_{15 i t}+\mathrm{e}$

Sumber: Bennouri et al. (2018)

Keterangan:

$\mathrm{Y}_{2 i t}=\mathrm{ROE}$ perusahaan asuransi jiwa ke-i pada periode $\mathrm{t}$

$\boldsymbol{\gamma}=$ Konstanta

$\mathrm{X}_{1 i t}=$ Female directorship (direktur) perusahaan asuransi jiwa ke-i pada periode $\mathrm{t}$

$\mathrm{X}_{2 i t}=$ Female directorship (komisaris) perusahaan asuransi jiwa ke-i pada periode $\mathrm{t}$

$\mathrm{X}_{3 i t}=$ Educational level of female directors perusahaan asuransi jiwa ke-i pada periode $\mathrm{t}$

$\mathrm{X}_{4 i t}=$ Educational level of commissioners perusahaan asuransi jiwa ke-i pada periode $\mathrm{t}$

$\mathrm{X}_{5 i t}=$ Business expertise of female directors perusahaan asuransi jiwa ke-i pada periode $\mathrm{t}$

$\mathrm{X}_{6 i t}=$ Business expertise of female commissioners perusahaan asuransi jiwa ke-i pada periode $\mathrm{t}$

$\mathrm{X}_{7 i t}=$ Female board multi-directorship (direktur) perusahaan asuransi jiwa ke-i pada periode $\mathrm{t}$

$\mathrm{X}_{8 i t}=$ Female board multi-directorship (komisaris) perusahaan asuransi jiwa ke-i pada periode $\mathrm{t}$

$\mathrm{X}_{9 i t}=$ Tenure of female directors perusahaan asuransi jiwa ke-i pada periode $\mathrm{t}$

$\mathrm{X}_{10 i t}=$ Tenure of female commissioner perusahaan asuransi jiwa ke-i pada periode $\mathrm{t}$

$\mathrm{X}_{11 i t}=$ Board size (direksi) perusahaan asuransi jiwa ke-i pada periode $\mathrm{t}$

$\mathrm{X}_{12 i t}=$ Board size (komisaris) perusahaan asuransi jiwa ke-i pada periode $\mathrm{t}$

$\mathrm{X}_{13 i t}=$ Board independence perusahaan asuransi jiwa ke-i pada periode $\mathrm{t}$

$\mathrm{X}_{14 i t}=$ leverage perusahaan asuransi jiwa ke-i pada periode $\mathrm{t}$

$\mathrm{X}_{15 i t}=$ firm size perusahaan asuransi jiwa ke-i pada periode $\mathrm{t}$

$\boldsymbol{\theta}_{1-15}=$ Koefisien parameter $\mathrm{X}_{1-15}$

$\mathrm{e}=$ error

\section{HASIL DAN PEMBAHASAN}

Tabel 2 menunjukkan statistik deskriptif dari penelitian terhadap 22 perusahaan asuransi jiwa di Indonesia periode 2014-2018.

Tabel 2. Statistik Deskriptif

\begin{tabular}{|c|c|c|c|c|c|}
\hline & $\mathrm{N}$ & Mean & Minimum & Maksimum & $\begin{array}{l}\text { Std. } \\
\text { Deviasi }\end{array}$ \\
\hline \multirow{2}{*}{$\begin{array}{l}\text { ROA } \\
R O E\end{array}$} & 110 & $-2,0$ persen & $-54,7$ persen & 7,1 persen & 14 persen \\
\hline & 110 & $-7,3$ persen & $-162,6$ persen & 47,5 persen & 53 persen \\
\hline $\begin{array}{l}\text { Female directorship } \\
\text { (direktur) } \\
\text { Female directorship }\end{array}$ & 110 & 23,1 persen & 0,0 persen & 66,7 persen & 21 persen \\
\hline $\begin{array}{l}\text { (komisaris) } \\
\text { Educational level of }\end{array}$ & 110 & 16,4 persen & 0,0 persen & 50,0 persen & 16 persen \\
\hline $\begin{array}{l}\text { female director } \\
\text { Educational level of } \\
\text { female }\end{array}$ & 110 & 47,7 persen & 0,0 persen & 100,0 persen & 50 persen \\
\hline commissioners & 110 & 22,7 persen & 0,0 persen & 100,0 persen & 43 persen \\
\hline
\end{tabular}


Lanjutan Tabel 2.

\begin{tabular}{|c|c|c|c|c|c|}
\hline $\begin{array}{l}\text { Business expertise of } \\
\text { female director } \\
\text { Business expertise of } \\
\text { female }\end{array}$ & 110 & 39,4 persen & 0,0 persen & 100,0 persen & 46 persen \\
\hline $\begin{array}{l}\text { commissioners } \\
\text { Female board multi- } \\
\text { directorship }\end{array}$ & 110 & 25,0 persen & 0,0 persen & 100,0 persen & 43 persen \\
\hline $\begin{array}{l}\text { (direktur) } \\
\text { Female board multi- } \\
\text { directorship }\end{array}$ & 110 & 4,5 persen & 0,0 persen & 100,0 persen & 21 persen \\
\hline $\begin{array}{l}\text { (komisaris) } \\
\text { Tenure of female }\end{array}$ & 110 & 11,4 persen & 0,0 persen & 100,0 persen & $\begin{array}{l}31 \text { persen } \\
348\end{array}$ \\
\hline $\begin{array}{l}\text { director } \\
\text { Tenure of female }\end{array}$ & 110 & 2,35 & 0 & 15 & $\begin{array}{l}\text { persen } \\
325\end{array}$ \\
\hline $\begin{array}{l}\text { commissioners } \\
\text { Board size }\end{array}$ & 110 & 2,5 & 0 & 11 & $\begin{array}{l}\text { persen } \\
171\end{array}$ \\
\hline $\begin{array}{l}\text { (direktur) } \\
\text { Board size }\end{array}$ & 110 & 4,36 & 3,00 & 9,00 & persen \\
\hline (komisaris) & 110 & 3,95 & 2,00 & 6,00 & 95 persen \\
\hline Board independence & 110 & 53,8 persen & 40,0 persen & 66,7 persen & 8 persen \\
\hline $\begin{array}{l}\text { Leverage } \\
\text { Firm Size }\end{array}$ & 110 & 73,0 persen & 14,6 persen & 93,5 persen & $\begin{array}{l}21 \text { persen } \\
179\end{array}$ \\
\hline & 110 & 28,78 & 24,35 & 31,62 & persen \\
\hline
\end{tabular}

Sumber: Data Penelitian, 2019

Female directorship direksi memiliki mean sebesar 23,06 persen, angka minimum dan juga maksimum sebesar 66,67 persen dan 0,0 persen serta memiliki standar deviasi sebesar 20,61 persen. Female directorship komisaris memiliki mean sebesar 16,44 persen, angka minimum dan juga maksimum sebesar 50, persen dan 0,0 persen serta memiliki standar deviasi sebesar 16,38 persen. Tingkat edukasi dari direksi wanita memiliki mean sebesar 47,73 persen, angka minimum dan juga maksimum sebesar 100 persen dan 0,0 persen serta memiliki standar deviasi sebesar 49,95 persen. Tingkat edukasi dari komisaris wanita memiliki mean sebesar 22,73 persen, angka minimum dan juga maksimum sebesar 100 persen dan 0,0 persen serta memiliki standar deviasi sebesar 42,89 persen. Business expertise dari direksi wanita memiliki mean sebesar 39,39 persen, angka minimum dan juga maksimum sebesar 100 persen dan 0,0 persen serta memiliki standar deviasi sebesar 46,45 persen. Business expertise dari komisaris wanita memiliki mean sebesar 25 persen, angka minimum dan juga maksimum sebesar 100, persen dan 0,0 persen serta memiliki standar deviasi sebesar 42,96 persen. Multi-directorship dari direksi wanita memiliki mean sebesar 4,55 persen, angka minimum dan juga maksimum sebesar 100 persen dan 0,0 persen serta memiliki standar deviasi sebesar 21,32 persen. Multi-directorship dari komisaris wanita memiliki mean sebesar 11,36 persen, angka minimum dan juga maksimum sebesar 100 persen dan 0,0 persen serta memiliki standar deviasi sebesar 30,6 persen. Masa jabatan dari direksi wanita memiliki mean sebesar 2,35 tahun, angka minimum dan juga maksimum sebesar 15 tahun dan 0 tahun serta memiliki standar deviasi sebesar 3,48. Masa jabatan dari komisaris wanita 
memiliki mean sebesar 2,5 tahun, angka minimum dan juga maksimum sebesar 11 tahun dan 0 tahun serta memiliki standar deviasi sebesar 3,25

Board size dari direksi memiliki mean sebesar 4,36 orang (dibulatkan menjadi 4 orang), angka minimum dan juga maksimum sebesar 9 orang dan 3 orang serta memiliki standar deviasi sebesar 1,71. Board size dari komisaris memiliki mean sebesar 3,95 orang (dibulatkan menjadi 4 orang), angka minimum dan juga maksimum sebesar 6 orang dan 2 orang serta memiliki standar deviasi sebesar 0,95. Independensi dewan komisaris memiliki mean sebesar 53,79 persen, angka minimum dan juga maksimum sebesar 66,67 persen dan 40, persen serta memiliki standar deviasi sebesar 7,79 persen. Leverage memiliki mean sebesar 73,01 persen, angka minimum dan juga maksimum sebesar 93,46 persen dan 14,63 persen serta memiliki standar deviasi sebesar 20,87 persen. Ukuran perusahaan (dalam $\ln$ total aset) memiliki mean sebesar 28,78, angka minimum dan juga maksimum sebesar 31,62 dan 24,35 serta memiliki standar deviasi 179 persen.

Uji asumsi klasik digunakan agar model regresi menghasilkan parameter yang tidak bias. Berikut adalah hasil pengujian asumsi klasik:

\section{Tabel 3. Uji Asumsi Klasik}

\begin{tabular}{|c|c|c|c|c|c|c|c|}
\hline \multirow[t]{2}{*}{ Variabel } & \multirow{2}{*}{\begin{tabular}{|l}
$\begin{array}{c}\text { Multi- } \\
\text { kolineritas }\end{array}$ \\
VIF
\end{tabular}} & \multicolumn{2}{|c|}{$\begin{array}{c}\text { Hetero- } \\
\text { skedastisitas }\end{array}$} & \multicolumn{2}{|c|}{ Normalitas } & \multicolumn{2}{|c|}{ Autokorelasi } \\
\hline & & $\begin{array}{l}\text { Pers. } \\
1 \\
\text { (sig.) }\end{array}$ & $\begin{array}{l}\text { Pers. } 2 \\
\text { (sig.) }\end{array}$ & $\begin{array}{l}\text { Pers. } \\
1 \\
\text { (sig.) }\end{array}$ & $\begin{array}{l}\text { Pers. } \\
2 \\
\text { (sig.) }\end{array}$ & $\begin{array}{l}\text { Pers. } 1 \\
\text { (sig.) }\end{array}$ & $\begin{array}{l}\text { Pers. } 2 \\
\text { (sig.) }\end{array}$ \\
\hline Model ROA & - & 0,000 & - & 0,000 & - & 0,724 & - \\
\hline Model ROE & - & - & 0,000 & - & 0,254 & - & 0,000 \\
\hline $\begin{array}{l}\text { Female } \\
\text { directorship } \\
\text { (direktur) }\end{array}$ & 2,44 & - & - & - & - & - & - \\
\hline $\begin{array}{l}\text { Female } \\
\text { directorship } \\
\text { (komisaris) }\end{array}$ & 4,09 & - & - & - & - & - & - \\
\hline $\begin{array}{l}\text { Educational level } \\
\text { of female director }\end{array}$ & 4,76 & - & - & - & - & - & - \\
\hline $\begin{array}{l}\text { Educational level } \\
\text { of female } \\
\text { commissioners }\end{array}$ & 3,30 & - & - & - & - & - & - \\
\hline $\begin{array}{l}\text { Business } \\
\text { expertise of } \\
\text { female director }\end{array}$ & 4,35 & - & - & - & - & - & - \\
\hline $\begin{array}{l}\text { Business } \\
\text { expertise of } \\
\text { female } \\
\text { commissioners }\end{array}$ & 2,82 & - & - & - & - & - & - \\
\hline $\begin{array}{l}\text { Female board } \\
\text { multi- } \\
\text { directorship } \\
\text { (direktur) }\end{array}$ & 1,93 & - & - & - & - & - & - \\
\hline
\end{tabular}


Lanjutan Tabel 3.

\begin{tabular}{|c|c|c|c|c|c|c|c|}
\hline $\begin{array}{l}\text { Female board } \\
\text { multi- } \\
\text { directorship } \\
\text { (komisaris) }\end{array}$ & 2,44 & - & - & - & - & - & - \\
\hline $\begin{array}{l}\text { Tenure of female } \\
\text { director }\end{array}$ & 3,23 & - & - & - & - & - & - \\
\hline $\begin{array}{l}\text { Tenure of female } \\
\text { commissioners }\end{array}$ & 2,52 & - & - & - & - & - & - \\
\hline $\begin{array}{l}\text { Board size } \\
\text { (direktur) }\end{array}$ & 1,27 & - & - & - & - & - & - \\
\hline $\begin{array}{l}\text { Board size } \\
\text { (komisaris) }\end{array}$ & 1,51 & - & - & - & - & - & - \\
\hline $\begin{array}{l}\text { Board } \\
\text { independence }\end{array}$ & 1,35 & - & - & - & - & - & - \\
\hline Leverage & 1,40 & - & - & - & - & - & - \\
\hline Firm Size & 2,21 & - & - & - & - & - & - \\
\hline
\end{tabular}

Sumber: Data Penelitian, 2019

Pada pengujian multikolinearitas di tabel 3, dilakukan pengecekan apakah terdapat hubungan antara dua atau lebih variabel independen. Untuk melakukan pengecekan, dilakukan pengujian dengan nilai VIF (Variance Inflating Factor). Indikasi terdapat multikolinearitas adalah pada saat nilai VIF lebih besar dari 10. Berdasarkan tabel 3, tidak terdapat multikolinearitas karena nilai VIF menunjukkan nilai kurang dari 10.

Pada pengujian heteroskedastisitas, dilakukan pengecekan apakah varians error konstan atau tidak. Untuk melakukan pengecekan, dilakukan pengujian signifikansi dengan Breusch Pagan Test for Heteroskedasticity. Jika nilai pengujian lebih kecil daripada tingkat signifikansi (5 persen), maka terdapat heteroskedastisitas pada model. Berdasarkan tabel 2, terdapat heteroskedastisitas pada kedua model regresi (model ROA dan model ROE) dikarenakan nilai pengujian lebih kecil dari tingkat signifikansi (5 persen).

Pada pengujian normalitas, dilakukan pengecekan apakah error terdistribusi secara normal atau tidak. Untuk melakukan pengecekan, dilakukan pengujian signifikansi dengan Jarque Bera Test for Normality. Jika nilai pengujian lebih kecil daripada tingkat signifikansi (5 persen), maka error tidak terdistribusi secara normal. Berdasarkan tabel 3, error pada model ROA tidak terdistribusi secara normal dikarenakan memiliki nilai pengujian lebih kecil daripada tingkat signifikansi (5 persen). Error pada model ROE telah terdistribusi secara normal dikarenakan memiliki nilai pengujian lebih besar daripada tingkat signifikansi (5 persen).

Pada pengujian autokorelasi, dilakukan pengecekan apakah error antar observasi saling berhubungan atau tidak. Untuk melakukan pengecekan, dilakukan pengujian signifikansi dengan Wooldridge Test for Autocorrelation. Jika nilai pengujian lebih kecil daripada tingkat signifikansi (5 persen), maka error antar observasi saling berhubungan. Berdasarkan tabel 3, error antar observasi pada model ROE saling berhubungan dikarenakan memiliki nilai pengujian lebih kecil daripada tingkat signifikansi (5 persen). Error antar observasi pada model 
ROA tidak berhubungan dikarenakan memiliki nilai pengujian lebih besar daripada tingkat signifikansi (5 persen).

Berdasarkan uji asumsi klasik pada tabel 3, dapat diketahui bahwa pada model ROA terdapat masalah heteroskedastisitas dan non-normalitas error. Pada model ROE terdapat masalah heteroskedastisitas dan autokorelasi. Untuk menghilangkan permasalahan ini, peneliti memutuskan untuk membuat model regresi yang robust (robust regression model). Hasil regresi dengan model robust ditunjukkan pada tabel berikut:

Tabel 4. Hasil Analisis Regresi Linier Berganda (Persamaan 1: ROA)

\begin{tabular}{|c|c|c|c|c|}
\hline $\begin{array}{l}\text { Model } \\
\text { (ROA) }\end{array}$ & Koefisien & t-test & $\begin{array}{c}\text { Probabilitas } \\
\text { (Sig.) }\end{array}$ & $\begin{array}{c}\text { Hasil } \\
\text { Uji Hipotesis }\end{array}$ \\
\hline $\begin{array}{l}\text { Female directorship } \\
\text { (direktur) }\end{array}$ & $-0,0098$ & $-0,12$ & 0,903 & Gagal Ditolak \\
\hline $\begin{array}{l}\text { Female directorship } \\
\text { (komisaris) }\end{array}$ & 0,3880 & 2,97 & 0,004 & Ditolak \\
\hline $\begin{array}{l}\text { Educational level of } \\
\text { female director } \\
\text { Educational level of } \\
\text { female }\end{array}$ & $-0,0841$ & $-2,53$ & 0,013 & Ditolak \\
\hline commissioners & $-0,1853$ & $-4,66$ & 0,000 & Ditolak \\
\hline $\begin{array}{l}\text { Business expertise of } \\
\text { female director } \\
\text { Business expertise of } \\
\text { female }\end{array}$ & 0,0440 & 1,3 & 0,196 & Gagal Ditolak \\
\hline $\begin{array}{l}\text { commissioners } \\
\text { Female board multi- } \\
\text { directorship }\end{array}$ & $-0,0969$ & $-2,26$ & 0,026 & Ditolak \\
\hline $\begin{array}{l}\text { (direktur) } \\
\text { Female board multi- } \\
\text { directorship }\end{array}$ & 0,1063 & 3,1 & 0,003 & Ditolak \\
\hline (komisaris) & $-0,3290$ & $-5,34$ & 0,000 & Ditolak \\
\hline $\begin{array}{l}\text { Tenure of female } \\
\text { director } \\
\text { Tenure of female }\end{array}$ & 0,0033 & 0,75 & 0,452 & Gagal Ditolak \\
\hline $\begin{array}{l}\text { commissioners } \\
\text { Board size }\end{array}$ & 0,0056 & 0,89 & 0,377 & Gagal Ditolak \\
\hline $\begin{array}{l}\text { (direktur) } \\
\text { Board size }\end{array}$ & $-0,0038$ & $-0,61$ & 0,540 & Gagal Ditolak \\
\hline (komisaris) & $-0,0594$ & $-3,67$ & 0,000 & Ditolak \\
\hline Board independence & $-0,0996$ & $-1,07$ & 0,288 & Gagal Ditolak \\
\hline Leverage & 0,0273 & 0,52 & 0,603 & Gagal Ditolak \\
\hline Firm Size & $-0,0072$ & $-0,89$ & 0,378 & Gagal Ditolak \\
\hline Konstanta & 0,5059 & 2,07 & 0,041 & - \\
\hline R-squared & 0,7108 & & & \\
\hline Sig. F & 0,0000 & & & \\
\hline
\end{tabular}


Berdasarkan tabel 4 dapat disusun persamaan pooled least square multiple regression sebagai berikut:

$\mathrm{Y}_{1 i t}=0,5059-0,0098 \mathrm{X}_{1 i t}+0,3880 \mathrm{X}_{2 i t}-0,0841 \mathrm{X}_{3 i t}-0,1853 \mathrm{X}_{4 i t}+0,044 \mathrm{X}_{5 i t}-0,0969 \mathrm{X}_{6 i t}$ $+0,1063 X_{7 i t}-0,329 X_{8 i t}+0,0033 X_{9 i t}+0,0056 X_{10 i t}-0,0038 X_{11 i t}-0,0594 X_{12 i t}-$ $0,0996 X_{13 i t}+0.0273 X_{14 i t}-0.0072 X_{15 i t}$

Berdasarkan persamaan regresi tersebut, maka dapat dilihat bahwa koefisien parameter dari female directorship (direktur) bernilai -0,0098, berarti jika komposisi wanita dalam jajaran direksi bertambah 1 persen maka return on asset akan menurun sebesar 0,98 persen, ceteris paribus. Koefisien parameter dari female directorship (komisaris) bernilai 0,38804 berarti jika komposisi wanita dalam jajaran dewan komisaris bertambah 1 persen maka return on asset mengalami kenaikan sebesar 38,804 persen, ceteris paribus.

Koefisien parameter dari educational level of female director sebesar $-0,08412$ berarti jika komposisi direksi wanita yang berpendidikan S2 di atas bertambah 1 persen maka return on asset mengalami penurunan sebesar 8,41 persen, ceteris paribus. Koefisien parameter dari educational level of female commissioners bernilai 0,1853 berarti jika komposisi komisaris wanita yang berpendidikan di atas S2 bertambah 1 persen maka return on asset mengalami penurunan sebesar 18,53 persen, ceteris paribus.

Koefisien parameter dari business expertise of female director bernilai 0,044 berarti jika komposisi direksi wanita yang memiliki keahlian bisnis bertambah 1 persen maka return on asset mengalami kenaikan sebesar 4,4 persen, ceteris paribus. Koefisien parameter dari business expertise of female commissioners bernilai -0,0969 berarti jika komposisi komisaris wanita yang memiliki keahlian bisnis bertambah 1 persen maka return on asset mengalami penurunan sebesar 9,69 persen, ceteris paribus.

Koefisien parameter dari female multi-board directorship (direktur) bernilai 0,1063 berarti jika komposisi direksi wanita yang merangkap jabatan bertambah 1 persen maka return on asset mengalami kenaikan sebesar 10,63 persen, ceteris paribus. Koefisien parameter dari female multi-board directorship (komisaris) bernilai -0,329 berarti jika komposisi dewan komisaris wanita yang merangkap jabatan bertambah 1 persen maka return on asset mengalami penurunan sebesar 32,9 persen, ceteris paribus.

Koefisien parameter dari tenure of female director bernilai 0,0033 berarti jika lama waktu direksi wanita menjabat bertambah 1 tahun maka return on asset mengalami kenaikan sebesar 0,33 persen, ceteris paribus. Koefisien parameter dari tenure of female commissioners bernilai 0,0056 berarti jika lama waktu komisaris wanita menjabat bertambah 1 tahun maka return on asset mengalami kenaikan sebesar 0,56 persen, ceteris paribus.

Koefisien parameter dari board size (direktur) bernilai -0,00382 berarti jika komposisi direktur dalam jajaran direksi bertambah 1 orang maka return on asset mengalami penurunan sebesar 0,382 persen, ceteris paribus. Koefisien parameter dari board size (komisaris) bernilai -0,0594 berarti jika komposisi direktur dalam jajaran direksi bertambah 1 orang maka return on asset mengalami penurunan sebesar 5,94 persen, ceteris paribus. 
Koefisien parameter dari board independence bernilai -0,0996 berarti jika komposisi komisaris independen dalam dewan komisaris bertambah 1 persen maka return on asset mengalami penurunan sebesar 9,96 persen, ceteris paribus.

Koefisien parameter dari leverage bernilai 0,02733 berarti jika komposisi debt terhadap asset bertambah 1 persen maka return on asset mengalami kenaikan sebesar 2,733 persen, ceteris paribus.

Koefisien parameter dari firm size bernilai -0,0072 berarti jika nilai logaritma natural dari aset bertambah 1 poin maka return on asset mengalami penurunan sebesar 0,72 persen, ceteris paribus.

Koefisien determinasi untuk model regresi pertama (ROA) adalah 0.7108. Hal ini menandakan bahwa 71,08 persen variasi pada return on asset dapat dijelaskan oleh variabel independennya sedangkan sisanya 28,92 persen variasi pada variabel return on asset tidak dapat dijelaskan oleh model.

Tabel 5. Hasil Analisis Regresi Linier Berganda (Persamaan 2: Model ROE)

\begin{tabular}{|c|c|c|c|c|}
\hline $\begin{array}{l}\text { Model } \\
\text { (ROE) }\end{array}$ & Koefisien & t-test & $\begin{array}{l}\text { Probabilitas } \\
\text { (Sig.) }\end{array}$ & $\begin{array}{c}\text { Hasil } \\
\text { Uji Hipotesis }\end{array}$ \\
\hline $\begin{array}{l}\text { Female directorship } \\
\text { (direktur) }\end{array}$ & 0,06058 & 0,25 & 0,803 & Gagal Ditolak \\
\hline $\begin{array}{l}\text { Female directorship } \\
\text { (komisaris) }\end{array}$ & 0,63088 & 1,65 & 0,102 & Gagal Ditolak \\
\hline $\begin{array}{l}\text { Educational level of } \\
\text { female director } \\
\text { Educational level of } \\
\text { female }\end{array}$ & $-0,4045$ & $-3,24$ & 0,002 & Ditolak \\
\hline $\begin{array}{l}\text { commissioners } \\
\text { Business expertise of }\end{array}$ & $-0,4643$ & $-3,59$ & 0,001 & Ditolak \\
\hline $\begin{array}{l}\text { female director } \\
\text { Business expertise of } \\
\text { female }\end{array}$ & 0,20386 & 1,61 & 0,111 & Gagal Ditolak \\
\hline $\begin{array}{l}\text { commissioners } \\
\text { Female board multi- } \\
\text { directorship }\end{array}$ & $-0,2071$ & $-2,08$ & 0,040 & Ditolak \\
\hline $\begin{array}{l}\text { (direktur) } \\
\text { Female board multi- } \\
\text { directorship }\end{array}$ & 0,45164 & 3,6 & 0,001 & Ditolak \\
\hline $\begin{array}{l}\text { (komisaris) } \\
\text { Tenure of female }\end{array}$ & $-0,7973$ & $-4,25$ & 0,000 & Ditolak \\
\hline $\begin{array}{l}\text { director } \\
\text { Tenure of female }\end{array}$ & 0,01007 & 0,79 & 0,429 & Gagal Ditolak \\
\hline $\begin{array}{l}\text { commissioners } \\
\text { Board size }\end{array}$ & 0,01729 & 1,06 & 0,293 & Gagal Ditolak \\
\hline $\begin{array}{l}\text { (direktur) } \\
\text { Board size }\end{array}$ & 0,00188 & 0,11 & 0,916 & Gagal Ditolak \\
\hline (komisaris) & $-0,1283$ & $-3,38$ & 0,001 & Ditolak \\
\hline Board independence & $-0,3066$ & $-1,11$ & 0,268 & Gagal Ditolak \\
\hline Leverage & 0,19411 & 1,43 & 0,157 & Gagal Ditolak \\
\hline
\end{tabular}

Bersambung ... 
Lanjutan Tabel 5

\begin{tabular}{llllc}
\hline Firm Size & $-0,0234$ & $-1,09$ & 0,278 & Gagal Ditolak \\
Konstanta & 1,31067 & 1,92 & 0,058 & - \\
R-squared & 0,7064 & & & \\
Sig. F & 0,0000 & & & \\
\hline
\end{tabular}

Sumber: Data Penelitian, 2019

Berdasarkan tabel 5 dapat disusun persamaan pooled least square multiple regression sebagai berikut:

$\mathrm{Y}_{2 i t}=1,3107+0,0606 \mathrm{X}_{1 i t}+0,6309 \mathrm{X}_{2 i t}-0,4045 \mathrm{X}_{3 i t}-0,4643 \mathrm{X}_{4 i t}+0,2039 \mathrm{X}_{5 i t}-$ $0,2071 X_{6 i t}+0,4516 X_{7 i t}-0,7973 X_{8 i t}+0,0101 X_{9 i t}+0,0173 X_{10 i t}+0,0019 X_{11 i t}-0,1283 X_{12 i t}$ $-0,3066 X_{13 i t}+0,1941 X_{14 i t}-0,0234 X_{15 i t}$

Berdasarkan persamaan regresi di atas maka dapat dilihat bahwa koefisien parameter dari female directorship (direktur) bernilai 0,0606, berarti jika komposisi wanita dalam jajaran direksi bertambah 1 persen maka return on equity mengalami kenaikan sebesar 6,06 persen, ceteris paribus. Koefisien parameter dari female directorship (komisaris) bernilai 0,6309 berarti jika komposisi wanita dalam jajaran dewan komisaris bertambah 1 persen maka return on equity mengalami kenaikan sebesar 63,09 persen, ceteris paribus.

Koefisien parameter dari educational level of female director bernilai -0,4045 berarti jika komposisi direksi wanita yang berpendidikan S2 di atas bertambah 1 persen maka return on equity mengalami penurunan sebesar 40,45 persen, ceteris paribus. Koefisien parameter dari educational level of female commissioners bernilai 0,4643 berarti jika komposisi komisaris wanita yang berpendidikan di atas S2 bertambah 1 persen maka return on equity mengalami penurunan sebesar 46,43 persen, ceteris paribus.

Koefisien parameter dari business expertise of female director bernilai 0,2039 berarti jika komposisi direksi wanita yang memiliki keahlian bisnis bertambah 1 persen maka return on equity mengalami kenaikan sebesar 20,39 persen, ceteris paribus. Koefisien parameter dari business expertise of female commissioners bernilai -0,2071 berarti jika komposisi komisaris wanita yang memiliki keahlian bisnis bertambah 1 persen maka return on equity mengalami penurunan sebesar 20,71 persen, ceteris paribus.

Koefisien parameter dari female multi-board directorship (direktur) bernilai 0,4516 berarti jika komposisi direksi wanita yang merangkap jabatan bertambah 1 persen maka return on equity mengalami kenaikan sebesar 45,16 persen, ceteris paribus. Koefisien parameter dari female multi-board directorship (komisaris) bernilai -0,7973 berarti jika komposisi dewan komisaris wanita yang merangkap jabatan bertambah 1 persen maka return on equity mengalami penurunan sebesar 79,73 persen, ceteris paribus.

Koefisien parameter dari tenure of female director bernilai 0,0101 berarti jika lama waktu direksi wanita menjabat bertambah 1 tahun maka return on equity mengalami kenaikan sebesar 1,01 persen, ceteris paribus. Koefisien parameter dari tenure of female commissioners bernilai 0,0173 berarti jika lama waktu komisaris wanita menjabat bertambah 1 tahun maka return on equity mengalami kenaikan sebesar 1,73 persen, ceteris paribus. 
Koefisien parameter dari board size (direktur) bernilai 0,0019 berarti jika komposisi direktur dalam jajaran direksi bertambah 1 orang maka return on equity mengalami kenaikan sebesar 0,19 persen, ceteris paribus. Koefisien parameter dari board size (komisaris) bernilai -0,1283 berarti jika komposisi direktur dalam jajaran direksi bertambah 1 orang maka return on equity mengalami penurunan sebesar 12,83 persen, ceteris paribus.

Koefisien parameter dari board independence bernilai -0,3066 berarti jika komposisi komisaris independen dalam dewan komisaris bertambah 1 persen maka return on equity mengalami penurunan sebesar 30,66 persen, ceteris paribus. Koefisien parameter dari leverage bernilai 0,1941 berarti jika komposisi debt terhadap asset bertambah 1 persen maka return on equity mengalami kenaikan sebesar 19,41 persen, ceteris paribus. Koefisien parameter dari firm size bernilai 0,0234 berarti jika nilai logaritma natural dari aset bertambah 1 poin maka return on equity mengalami penurunan sebesar 2,34 persen, ceteris paribus.

Koefisien determinasi untuk model regresi pertama (ROE) adalah 0,7064. Hal ini menandakan bahwa 70,64 persen variasi pada return on equity dapat dijelaskan oleh variabel independennya sedangkan sisanya 29,36 persen variasi pada variabel return on equity tidak dapat dijelaskan oleh model.

Uji regresi yang dilakukan diperoleh pada Tabel 4 dan 5. Berdasarkan Tabel 4 dan 5, female directorship komisaris berpengaruh positif signifikan pada performa perusahaan yakni ROA. Hal ini berarti bahwa dengan adanya komisaris wanita dalam jajaran dewan komisaris menyebabkan semakin tingginya nilai ROA. Hasil tersebut sejalan dengan Bennouri et al. (2018) yang menemukan bahwa female directorship signifikan meningkatkan performa perusahaan.

Educational level of female director tidak berpengaruh signifikan terhadap ROA namun berpengaruh signifikan negatif pada ROE. Hal ini berarti bahwa semakin besar komposisi direksi wanita menyebabkan semakin rendah nilai ROE. Hal ini tidak sejalan dengan teori Bennouri et al. (2018) di mana seharusnya dengan adanya direktur wanita dalam komposisi direksi berpengaruh positif terhadap performa perusahaan. Perbedaaan ini disebabkan karena adanya anomali pada data ROE perusahaan asuransi jiwa di Indonesia, dimana nilai minimum ROE dalam sampel adalah $-162,6$ persen. Nilai rerata jumlah komposisi wanita dalam jajaran direktur juga tidak menyentuh angka 25 persen.

Educational level of female commissioners berpengaruh signifikan negatif pada ROA dan ROE. Berdasarkan Bennouri et al. (2018), semakin tinggi tingkat edukasi direktur dan komisaris berpengaruh positif terhadap ROA dan ROE. Menurut Johnson et al., (2013) penelitian terdahulu, semakin tinggi tingkat edukasi direktur dan komisaris, semakin direktur dan komisaris tersebut dapat memahami, menganalisis, dan menawarkan solusi terhadap masalah yang kompleks. Namun dalam kasus ini, tingkat edukasi direksi wanita memberikan dampak negatif terhadap ROE. Hasil tersebut sejalan dengan Jalbert, Ramesh, \& Jalbert (2002) yang mengatakan bahwa tingkat edukasi memberikan dampak negatif terhadap performa perusahaan dan kompensasi dikarenakan direktur yang tidak memiliki gelar pendidikan memiliki performa yang lebih baik dibandingkan direksi yang memiliki gelar pendidikan. 
Business expertise of female commissioners berpengaruh signifikan negatif terhadap performa perusahaan dari segi ROA dan ROE. Hal ini tidak sejalan dengan Bennouri et al. (2018), dimana pada penelitian tersebut, business expertise berpengaruh positif signifikan pada perusahaan berukuran besar dan berpengaruh signifikan negatif terhadap perusahaan berukuran kecil. Namun hasil tersebut sejalan dengan Darmadi (2011) menunjukkan bahwa adanya wanita dengan business expertise mempengaruhi performa perusahaan di Indonesia secara negatif dikarenakan penunjukkan wanita sebagai direktur didorong oleh hubungan keluarga dibandingkan dengan pengalaman dan keahlian kerja yang pada akhirnya menurunkan performa perusahaan.

Female board multi-directorship dari direktur berpengaruh positif signifikan terhadap ROA dan ROE, sejalan dengan penemuan dari Hillman et al., (2012). Namun female board multi-directorship dari dewan komisaris berpengaruh signifikan negatif terhadap ROA dan ROE, sejalan dengan penemuan López Iturriaga \& Morrós Rodríguez (2014) yang menyatakan bahwa direktur yang berada di terlalu banyak jajaran akan berpengaruh negatif terhadap performa perusahaan.

Board size (komisaris) berpengaruh signifikan negatif terhadap ROA dan ROE. Walaupun tidak sejalan dengan jurnal acuan, hasil tersebut sejalan dengan Guest (2009), yang mengatakan bahwa ukuran jajaran memiliki pengaruh yang negatif terhadap performa perusahaan.

\section{SIMPULAN}

Penelitian ini digunakan untuk menguji apakah terdapat pengaruh direksi dan komisaris wanita terhadap performa perusahaan asuransi jiwa di Indonesia pada periode 2014-2018. Simpulan dari penelitian ini adalah tingkat edukasi pada dewan komisaris dan direksi memiliki pengaruh signifikan negatif terhadap performa perusahaan (ROE, namun pada ROA hanya tingkat edukasi pada dewan komisaris saja yang berpengaruh signifikan negatif). Female board multidirectorship dari direktur secara signifikan memiliki pengaruh positif terhadap performa perusahaan. Terakhir, Board size (komisaris) berpengaruh signifikan negatif terhadap performa perusahaan. Implikasi dari penelitian ini dapat digunakan oleh praktisi di asuransi jiwa di Indonesia dalam menentukan komposisi wanita pada dewan komisaris dan direksi sehingga dapat memaksimalkan performa perusahaan.

Keterbatasan penelitian adalah penggunaan sampel asuransi jiwa yang berjumlah 22 perusahaan tahun 2014-2018. Sehingga penelitian ini masih kekurangan sampel untuk dapat melakukan generalisir terhadap pengaruh dewan komisaris dan direksi wanita terhadap performa perusahaan pada perusahaan asuransi jiwa. Bagi peneliti selanjutnya, disarankan untuk menambah sampel penelitian dan memperluas tidak hanya asuransi jiwa namun asuransi jenis lain, serta dapat menambahkan rentang waktu pengamatan yang lebih panjang. Terakhir, peneliti selanjutnya juga dapat memperbanyak variabelvariabel lain yang juga memengaruhi performa perusahaan sehingga model semakin baik. 


\section{REFERENSI}

Adams, R. B., \& Ferreira, D. (2009). Women in the boardroom and their impact on governance and performance. Journal of Financial Economics. https://doi.org/https://doi.org/10.1016/j.jfineco.2008.10.007

Alex, M. K., \& Ngaba, D. (2018). Effect of Firm Size on Financial Performance on Banks: Case of Commercial Banks in KenyaNo Title. International Academic Journal of Economics and Finance, 3(1), 175-190.

Bennouri, M., Chtioui, T., Nagati, H., \& Nekhili, M. (2018). Female board directorship and firm performance: What really matters? Journal of Banking and Finance. https://doi.org/10.1016/j.jbankfin.2017.12.010

Bhagat, S., \& Bolton, B. (2019). Corporate governance and firm performance: The sequel. Journal of Corporate Finance. https://doi.org/10.1016/j.jcorpfin.2019.04.006

Campbell, K., \& Mínguez-Vera, A. (2008). Gender diversity in the boardroom and firm financial performance. Journal of Business Ethics. https://doi.org/10.1007/s10551-007-9630-y

Darmadi, S. (2011). Board Diversity and Firm Performance: The Indonesian Evidence. Corporate Ownership and Control Journal, 8(2), 450-466. https://doi.org/http://dx.doi.org/10.22495/cocv8i2c4p4

Doğan, M. (2013). Does Firm Size Affect The Firm Profitability? Evidence from Turkey. Research Journal of Finance and Accounting.

Fama, E. F. (1980). Banking in the theory of finance. Journal of Monetary Economics. https:// doi.org/10.1016/0304-3932(80)90017-3

Fauzi, F., \& Locke, S. (2012). Board structure, ownership structure and firm performance: A study of New Zealand listed-firms. Asian Academy of Management Journal of Accounting and Finance.

Guest, P. M. (2009). The impact of board size on firm performance: Evidence from the UK. European Journal of Finance. https://doi.org/10.1080/13518470802466121

Harris, I. G., \& Shimizu, K. (2004). Too busy to serve? an examination of the Influence of Overboarded Directors. Journal of Management Studies. https://doi.org/10.1111/j.1467-6486.2004.00453.x

Hillman, A. J., Harris, I. C., \& Cannella, A. A. (2012). Woman and racial minorities in the boardroom: How do directors differ? Journal of Management. 2063(02)00192-7 https://doi.org/https://doi.org/10.1016/S0149-

IFC. (2018). Global Diversity Tracker Report 2018. Retrieved October 15, 2019, from https://www.ifc.org/wps/wcm/connect/21f19cfe-9cce-4089-bfc1e4c38767394e/Board_Gender_Diversity_in_ASEAN.pdf?MOD=AJPERES\& $\mathrm{CVID}=\mathrm{mM0qVBn}$

Jalbert, T., Ramesh, R., \& Jalbert, M. (2002). Does School Matter? An Empirical Analysis Of CEO Education, Compensation, And Firm Performance. International Business $\mathcal{E}$ Economics Research Journal. https://doi.org/https://doi.org/10.19030/iber.v1i1.3882

Johnson, S. G., Schnatterly, K., \& Hill, A. D. (2013). Board Composition Beyond Independence: Social Capital, Human Capital, and Demographics. Journal of Management. https://doi.org/10.1177/0149206312463938 
Junyon, I., \& Xian, C. (2015). CEO Tenure and Financial Performance: A MetaAnalysis. Academy of Management Annual Meeting Proceedings.

López Iturriaga, F. J., \& Morrós Rodríguez, I. (2014). Boards of directors and firm performance: the effect of multiple directorships. Spanish Journal of Finance and Accounting / Revista Española de Financiación y Contabilidad. https://doi.org/10.1080/02102412.2014.913909

Maina, L. K., Olweny, T., \& Wanjau, K. (2018). Observed Leverage and Financial Performance of Listed Firms in Kenya. International Journal of Finance $\mathcal{E}$ Banking Studies (2147-4486). https:/ / doi.org/10.20525/ijfbs.v7i2.872

McDonald, M. L., Westphal, J. D., \& Graebner, M. E. (2008). What do they know? The effects of outside director acquisition experience on firm acquisition performance. Strategic Management Journal. https:/ / doi.org/10.1002/smj.704

Miller, T., \& Del Carmen Triana, M. (2009). Demographic diversity in the boardroom: Mediators of the board diversity-firm performance relationship. Journal of Management Studies. https://doi.org/10.1111/j.14676486.2009.00839.x

Milliken, F. J., \& Martins, L. L. (1996). Searching for Common Threads: Understanding the Multiple Effects of Diversity in Organizational Groups. The Academy of Management Review. https:/ / doi.org/10.2307/258667

OJK. (n.d.). Surat Edaran Otoritas Jasa Keuangan Nomor 10/SEOJK.05/2016 tentang Pedoman Penerapan Manajemen Risiko dan Laporan Hasil Penilaian Sendiri Penerapan Manajemen Risiko bagi Lembaga Keuangan Non-Bank.

Rosenstein, S., \& Wyatt, J. G. (1997). Inside directors, board effectiveness, and shareholder wealth. Journal of Financial Economics. https:/ / doi.org/10.1016/S0304-405X(97)00004-4

Ross, S. A., Westerfield, R. W., \& Bradford D. Jordan. (2012). Fundamentals of Corporate Finance. In Standard Edition. https://doi.org/10.1017/CBO9781107415324.004

Ruigrok, W., Peck, S., \& Tacheva, S. (2007). Nationality and gender diversity on Swiss corporate boards. Corporate Governance: An International Review. https://doi.org/10.1111/j.1467-8683.2007.00587.x

Sekaran, U. (2011). Research methods: A skill building approach. John Wiley \& Sons. Leadership \& Organization Development Journal.

Singh, V., Point, S., Moulin, Y., \& Davila, A. (2015). Legitimacy profiles of women directors on top french company boards. Journal of Management Development. https://doi.org/10.1108/JMD-10-2013-0129

Terjesen, S., Couto, E. B., \& Francisco, P. M. (2016). Does the presence of independent and female directors impact firm performance? A multicountry study of board diversity. Journal of Management and Governance. https:// doi.org/10.1007/s10997-014-9307-8

Terjesen, S., Sealy, R., \& Singh, V. (2009). Women directors on corporate boards: A review and research agenda. Corporate Governance: An International Review. https://doi.org/10.1111/j.1467-8683.2009.00742.x

Tsuruta, D. (2017). Variance of Firm Performance and Leverage of Small Businesses. Journal of Small Business Management. https://doi.org/10.1111/jsbm.12243 